\title{
Analysis of formal-informal transitions in the Ecuadorian \\ labour market
}

\author{
Adriana Patricia Vega Núñez
}

\begin{abstract}
The study analyses the transitions between the formal and informal labour markets using longitudinal data for Ecuador. First, we use transition matrices to characterize the short-run dynamics among the different labour statuses in Ecuador. Next, multinomial logit models are used to identify the factors that determine the probability of remaining in or moving across the formal and informal sectors. Education level, years of experience and wage differentials by sector have a significant effect on worker transitions, showing that benefits and costs vary depending on the individual's preferences and skills.
\end{abstract}

\section{Keywords}

Employment, labour market, informal sector, labour mobility, mathematical analysis, employment statistics, Ecuador

\section{JEL classification}

O170, R230, J420

\section{Author}

Adriana Patricia Vega Núñez is a doctoral candidate in the Department of Econometrics, Statistics and Applied Economics at the University of Barcelona, Spain. Email: adriana. vega.nunez@gmail.com. 


\section{Introduction}

Widespread informality is a characteristic of developing and transition economies. ${ }^{1}$ A diverse range of people are involved in informal economic activities in these countries and the effects on them are manifold. This persistent phenomenon remains a major challenge in the many countries seeking to reduce it. ${ }^{2}$ Charmes (2009) shows that informal employment has existed since it was first defined in the mid-1970s. Until the 2000s, informal employment trended upwards in several regions around the world. ${ }^{3}$ On average, over the last 30 years, informal employment has accounted for more than $47 \%$ of total non-agricultural employment in developing regions, approximately $24 \%$ in transition economies and more than 50\%, on average, in Latin America.

While researchers' definitions of the term vary, informality is usually associated with negative phenomena: unprotected workers, tax evasion, illegal activities, low productivity, low investment rates and so on. However, different schools of thought have emerged in the literature on the causes of informal employment. The main question is whether individuals or businesses exit the formal sector voluntarily, or whether they are excluded from it. There are two dominant schools of thought discussed in the World Bank publication, Informality: Exit and Exclusion (Perry and others, 2007).

The exclusionary view, which reflects the traditional thinking, points to a segmented market where people choose informal employment because it is the only alternative (De Soto, 2000). In that sense, informal workers would prefer formal jobs that offer higher wages and labour protection.

By contrast, the concept of the voluntary informal sector is diametrically opposed, in that workers choose from among the various jobs on offer and join the informal sector willingly. Maloney (2004) supports this, drawing on evidence from Latin America to posit that the informal sector is an unregulated microentrepreneurial sector and not a disadvantaged residual of segmented labour markets. Furthermore, Bosch and Maloney (2005) suggest that a considerable portion of workers in the informal sector, particularly the self-employed, enter the sector voluntarily. Accordingly, many forms of informal employment can offer desirable advantages, such as independence or training opportunities.

The aim of this study is to examine labour market dynamics across the different employment statuses and observe the characteristics that determine the probability of transition or continuance across the formal and informal sectors in Ecuador. The empirical analysis is based on the Ecuadorian Survey of Urban Employment, Unemployment and Underemployment (ENEMDU) for the period 2011-2012. The study was done by examining the flows across the following labour sectors: formal, informal, unemployed and outside the labour force. It contributes to the existing literature in two ways: first, the panel survey used, which tracks both formal and informal workers over two consecutive years, allows us to identify changes in the labour force over time; second, the study adds to the scarce data available for Ecuador. To this end, we created a transition matrix to map the dynamics of the market and interactions across the sectors. Additionally, since the transition matrix does not reflect the observable characteristics of workers, a multinomial logit analysis was used to identify these characteristics and determine the probability of choosing each labour sector.

\footnotetext{
1 Irrespective of the methods for measuring informality, it is high in Latin America (Perry and others, 2007). Informality has increased over time in Sub-Saharan Africa and Asia (Jütting and others, 2008).

2 According to Baccheta, Ernst and Bustamante (2009), on the basis of broad definitions of informality, countries in Africa, Asia and Latin America present persistent informality rates.

3 There has been a rising trend in informal employment in Sub-Saharan Africa, South and East Asia, Latin America, West Asia, North Africa and transition countries (Charmes, 2009).
} 
The article is divided into five sections. Following this introduction, section II provides a brief summary of empirical literature on the dynamics in the formal and informal labour market. Section III presents the data and definitions of informality and other main variables, as well as the econometric methodology and models used in the study. Section IV contains the results of the study. Lastly, in section $\mathrm{V}$, we discuss the main findings and present concluding remarks.

\section{Literature review}

As mentioned previously, two perspectives are used to explain the link between informality and segmentation in the labour market. The first assumes that workers would prefer formal wage employment, but are forced into the informal sector by restrictions and limited availability of formal jobs. In the model devised by Harris and Todaro (1970), setting a minimum wage above the equilibrium wage resulted in a limitation of formal jobs, leading to labour market segmentation.

In line with the second viewpoint, Maloney (1999) regards the formal and informal sectors as an integrated market in which workers choose their occupations from among the different jobs available on the basis of their preferences, abilities and needs. Thus, workers who prefer informal to formal employment do so because the former offers more desirable characteristics.

These two schools of thought examine the diverse flows in the labour market and the corresponding sectoral wage differentials in different ways. In a segmented market, flows from informal to formal jobs should exceed reverse flows. By comparison, in an integrated market, the flows between formal and informal jobs should occur in both directions and be similar in volume (Fields, 2009).

Recent evidence points to significant labour market mobility in emerging countries. The movement of workers across jobs, from unemployed to employed and into or out of the labour force indicate the mobility in a sector. In this regard, Maloney (1999) analysed worker transitions between sectors using panel data from Mexico, finding that patterns of labour market mobility indicate that much of the informal sector is a desirable destination and that the distinct modalities of work, formal and informal, are well integrated. Duryea and others (2006) examined evidence on worker flows across sectors in the labour market in three Latin American countries: Argentina, Mexico and the Bolivarian Republic of Venezuela. The authors found high mobility not only into and out of the labour market, but also across different types of jobs. They also found that, on average, workers who moved from formal wage to informal wage employment experienced a decline in earnings, while switching from informal to formal wage jobs produced the opposite effect. Cea and Contreras (2008) used panel data to provide evidence for Chile. The results revealed a strong tendency towards continuance in individuals' labour status. The study also suggests that age, schooling, and non-labour income are significant determinants of the probability of having a particular employment status. In a study on Argentina, Jiménez (2011) found evidence supporting segmentation of the formal sector of the labour market. In this case, one particular group of workers - unregistered wage earners - remained under unfavourable working conditions.

In their analysis of panel data from Ukraine, Lehmann and Pignatti (2008) found evidence of segmentation in the labour market such that moves by informal wage workers are largely involuntary. Slonimczyk and Gimpelson (2013), using a multinomial logit model and allowing for individual heterogeneity in preferences, point to the existence of an integrated labour market in the Russian Federation.

In general, informality is a prominent feature of transition and emerging economies, as is the mobility of workers across labour market sectors. These topics have been the subject of extensive research worldwide over the years, with diverse results. However, evidence from Ecuador is limited, as previous studies of the Ecuadorian labour market have mainly focused on wage distribution as opposed to effects on employment or transitions between the formal and informal sector. A recent study by 
Canelas (2014) examines whether changes in the minimum wage have an impact on formality and informality rates and wage levels in Ecuador. The results suggest that changes in the minimum wage do not affect employment rates and wages.

\section{Data and methodology}

The source of the data used in this study is the national survey (ENEMDU), a rotating household panel survey conducted by the National Statistics and Census Institute of Ecuador (INEC). The panel does not follow individuals continuously, but is constructed from four reports, spread over two consecutive years. Households are interviewed in two consecutive quarters, replaced by a new sample unit in the next two consecutive quarters and then returned one final time to the sample in two successive quarters. This national survey includes both urban and rural populations.

The panel analysed is the fourth quarter of 2011 to the fourth quarter of 2012. The analysis uses only one year's data because the results obtained from the separate transition tables calculated for previous years were quite similar to those in the panel evaluated in this study (see annex tables A1.1 and A1.2). The weights used reflect the expansion factors specified by INEC. The analysis includes workers aged 15 years and older.

In order to identify the different labour statuses that are used in the analysis, we can split the labour force into three major categories: employed, unemployed and outside the labour force. In addition, the employed category was divided into two further subdivisions: individuals in the formal sector and individuals in the informal sector, which included wage workers (in private companies or domestic work) and independent (self-employed) workers. We thus considered five different statuses in the labour market: (i) formal waged, (ii) informal waged, (iii) self-employed, (iv) unemployed and (v) outside the labour force. These divisions are made in the working-age population and are mutually exclusive. Individuals are classified as unemployed if they did not work in the reference week but had searched for a job. Outside the labour force refers to individuals who are not working or seeking some form of employment.

There are diverse definitions of informality, based on various criteria such as the size of production units or firms, or the number of employees and the type of employment relationship. The International Labour Organization (2013) defines the informal sector as a set of units engaged in the production of goods or services with the primary objective of generating employment and incomes for the persons concerned. These units typically operate at a low level of organization and on a small scale. Labour relations are based mostly on casual employment, kinship or personal and social relations rather than contractual arrangements with formal guarantees. In this context, and considering the data from the national survey, two definitions of the informal sector are used in this study. The first is related to the characteristics of the enterprise and encompasses wage employment in small, unregistered establishments with less than 10 employees, plus all independent and own-account work. The second is based on social security coverage: workers are considered to be in the informal sector if they are not covered by social security.

Figure 1 plots the informality rate based on the two above-mentioned definitions for the observation period 2011-2012. As the figure shows, the share of informal workers in the Ecuadorian labour force was between 32\% and 38\% in the observation period. In general, although Ecuador's informality rate may be considered high, it is within the average for informal employment in most Latin American countries. ${ }^{4}$

\footnotetext{
4 Between the 1970s and the 2000s, on average, informal employment accounted for more than $47 \%$ of total non-agricultural employment in West Asia and in North Africa, more than 70\% in sub-Saharan Africa, more than 50\% in Latin America, nearly 70\% in South and South-East Asia and 24\% in transition economies (Charmes, 2009).
} 
Figure 1

Ecuador: informal workers as a proportion of the total labour force, 2011-2012

(Percentages)

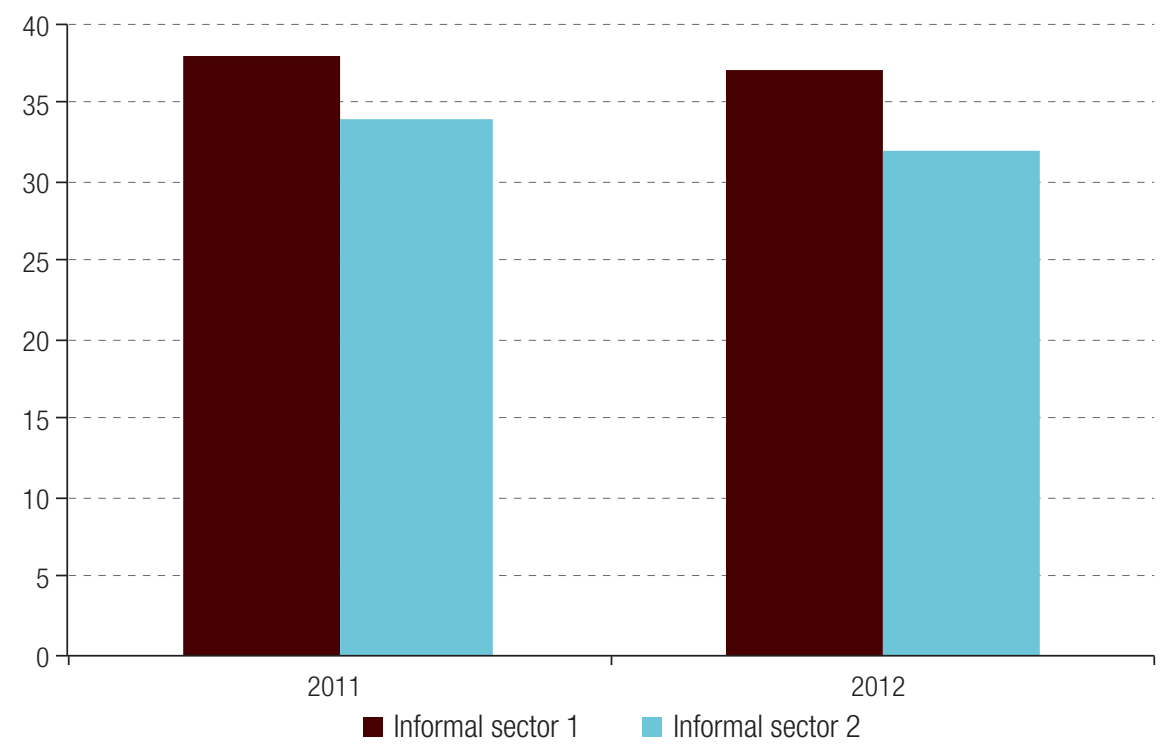

Source: Author's calculations, on the basis of the Ecuadorian Survey of Urban Employment, Unemployment and Underemployment, 2011-2012.

Note: Informal sector 1 is made up of wage workers employed in small unregistered establishments with less than 10 employees, plus all independent and self-employed workers. Informal sector 2 is made up of workers who have no social security coverage.

Considering the five labour statuses, 20 different transitions were identified to represent the flows across labour market sectors during the period analysed. We also included five states of continuance which indicate no change in labour status from the previous period. The analysis concentrates primarily on the movements from the formal and the informal sector (wage employment and self-employment) to each of the other labour statuses, in order to identify the characteristics of workers making these transitions. Annex table A1.3 shows the mean values for the sample using the first definition of informality, respectively, for age, level of schooling, work experience and the initial real wage for workers transitioning between or remaining in sectors. The initial and final real wages denote the monthly real wage of workers for December 2011 and December 2012, respectively (treating earnings from the main job as the only source of labour income). Finally, the earnings differential corresponds to the difference between the final and the initial real wage for workers moving to or remaining in a labour sector.

In the rest of this section, we describe the econometric techniques used in the study to provide empirical evidence of the mobility patterns across the aforementioned sectors of the Ecuadorian labour market. To identify the directions and volume of the various labour market flows, two methods were used: transition matrices and a multinomial logit analysis of movements between sectors.

\section{Transition matrices}

The transition matrices allow us to determine the flows of workers between the selected labour sectors by calculating the conditional probability of finding a worker in state $j$ at the end of the period, given that the worker began in state $i$; this is denoted by $P_{i j}$. The sum of each row of the transition matrix is equal to $100 \%$ and the totals at the end of the columns and rows represent the share of workers in each category at the end of the period $P_{i}$ and $P_{j}$. The components in the main diagonal reveal the share of workers who remained in the same labour category at the end of the period. The information provided by the transition matrices gives us a first idea of the different movements of workers between sectors. 


\section{Multinomial logit analysis of transitions between labour sectors}

Since the previous methodology is merely descriptive, we also use a multinomial logit analysis to determine which characteristics affect workers' probability of choosing to move to sector $j$ relative to the probability of staying in sector $i$. The multinomial logit model is a probabilistic discrete model which can explain tendencies to move or remain in the different sectors of the labour market. We can find the effect for each worker characteristic on the probability of transition into a sector. We model flows among five different labour market states: formal waged $(j=1)$, informal waged $(j=2)$, self-employed $(j=3)$, unemployed $(j=4)$, and outside the labour force $(j=5)$.

We use the standard exponential form for the multinomial logit analysis:

$$
P_{i j}=\frac{\exp \left(X_{i} \beta_{j}\right)}{\sum_{l=1}^{m} \exp \left(X_{i} \beta_{j}\right)}
$$

where the vector $\beta_{j}$ measures the degree to which an increase in worker characteristic $X_{i}$ increases the probability of a worker moving to state $j$ relative to the probability of staying in state $i$. The worker characteristics are age, gender, marital status, level of schooling, years of experience, region and earnings differential logarithms. We can calculate the probability of transition where the explanatory variables determine the increase or decrease in probabilities.

\section{Results}

\section{Transition matrices}

In the first analysis with transition matrices, we describe labour mobility by calculating the conditional probabilities of finding a worker in state $j$ at the end of the period, conditional on being in state $i$ initially. We therefore obtain a 5x5 annual matrix for the period analysed, December 2011 to December 2012 (see table 1). Since the purpose of this study is to identify the patterns of worker transitions out of and into the formal and informal sectors, we focus mainly on the transition from the formal sector to each of the other labour statuses and from the informal sector (both waged and self-employed) to the other sectors. The matrix also reveals some facts about the dynamics of the market and the relationships between the sectors defined.

Table 1

Ecuador: worker mobility across sectors of the labour market, 2011-2012

(Percentages)

\begin{tabular}{|c|c|c|c|c|c|c|c|}
\hline \multicolumn{8}{|c|}{ Final status } \\
\hline Initial status & $\begin{array}{l}\text { Formal } \\
\text { waged }\end{array}$ & $\begin{array}{l}\text { Informal } \\
\text { waged }\end{array}$ & $\begin{array}{l}\text { Informal self- } \\
\text { employed }\end{array}$ & Unemployed & $\begin{array}{l}\text { Outside the } \\
\text { labour force }\end{array}$ & Total & $P_{i}$ \\
\hline Formal waged & 79 & 6 & 6 & 2 & 6 & 100 & 25 \\
\hline Informal waged & 21 & 46 & 18 & 4 & 12 & 100 & 10 \\
\hline Informal self-employed & 8 & 7 & 67 & 1 & 16 & 100 & 25 \\
\hline Unemployed & 23 & 11 & 25 & 19 & 22 & 100 & 4 \\
\hline Outside the labour force & 4 & 4 & 8 & 3 & 81 & 100 & 36 \\
\hline$P_{j}$ & 26 & 10 & 24 & 3 & 37 & & \\
\hline
\end{tabular}

Source: Author's calculations on the basis of the Ecuadorian Survey of Urban Employment, Unemployment and Underemployment, 2011-2012.

Note: $\quad P_{i}$ is the relative size of a sector in the initial period; $P_{j}$ is the relative size of a sector in the final period. 
With regard to the movements of workers initially in the formal sector, we found a $79 \%$ continuance rate. Interestingly, the largest outflow from this sector is towards the informal category (12\% in total), in two distinct flows. The first is the movement into the informal wage sector (6\%) and reveals the deterioration in job conditions for workers in terms of formality. This particular type of labour transition could be explained by the rationalization of formal employment opportunities (Fields, 1972; Perry and others, 2007). The second is toward informal self-employment (6\%), which may be associated with voluntary decisions of individuals seeking more autonomy or the result of inefficiencies in formal sector protections and low levels of labour productivity (Maloney, 1999). Additionally, formal sector workers leaving their jobs could transition to unemployment (2\%) or out of the labour force (6\%).

Moves by informal wage workers paint a different picture. First, the probability of staying in this sector is around $46 \%$, meaning that these individuals prefer to seek other employment opportunities rather than remain in these jobs. If we look at the outflows from this segment of the informal sector, we find that $21 \%$ of workers obtained better quality jobs by switching to the formal sector. This type of mobility may be construed as workers improving their job conditions, given that workers in the informal sector typically earn less than similar workers in the formal sector (Günther and Launov, 2006). The other subdivision of the informal sector accounts for around $18 \%$ of outflows, highlighting the fact that wage workers in the informal sector seek not only formal-sector employment, but also self-employment. There are characteristics of the formal sector and self-employment -including, for the former, labour conditions and, the latter, independence - that make them somewhat more attractive than informal wage employment. Therefore, the probability of transition from informal wage employment to either formal or self-employment is higher than the probability of transition to unemployment. The flow from informal wage employment to outside the labour force is $12 \%$.

The third row of table 1 illustrates the transitions from self-employment. A first observation is that the continuance rate in this sector shows that a significant proportion of individuals remain selfemployed. A second is that the flows from self-employment to both the formal wage sector and the informal wage sector are quite similar ( $8 \%$ and $7 \%$, respectively), while transition to unemployment is $1 \%$. Mandelman and Montes-Rojas (2009) posit two possible reasons for transitions to the self-employed sector: the sector attracts individuals with outstanding entrepreneurial abilities, or it serves as a refuge for the unemployed. Either of these could explain the substantial continuance rate in this sector and the similar flows to the formal sector and to the informal wage sector.

We observed high mobility out of the unemployed sector, as only $19 \%$ of individuals remained unemployed during the observation period. Most of the unemployed transitioned to self-employment, followed by the formal sector and informal wage employment, at rates of $25 \%, 23 \%$, and $11 \%$, respectively.

Most of those who found jobs did so in the informal sector (wage and self-employment), which may be attributed to insufficient human capital or other individual worker characteristics or preferences. In the traditional view of unemployment as the lowest state in the labour market, individuals in this situation may have difficulty in entering the formal sector and thus be more likely to be propelled into accepting employment with inferior labour conditions and lower earnings. Jütting and others (2008) argue that it is also possible that working in the informal sector provides more advantages than the formal sector. After all, informality cannot be considered the last resort of a worker. Workers may voluntarily choose the informal sector, where they might have the opportunity to accumulate experience or training, particularly in the case of young low-skilled workers or unskilled older individuals, or find greater flexibility and autonomy. The World Bank (2012) highlights that entrepreneurs value the independence and flexibility of having their own business and may see being autonomous as the main reason to do so. 
Examination of the outside the labour force status shows a high continuance rate. Transitions into the self-employment, formal sector, informal wage and unemployed categories represented just $8 \%, 4 \%, 4 \%$ and $3 \%$, respectively. Here again, the total outflows to the informal sector are higher than those to the formal sector. In this context, it is apparent that the informal sector has some attractive characteristics for workers.

\section{Multinomial logit analysis}

The main objective of this section is to obtain an overview of the labour force dynamics in Ecuador. Thus, the informal sector, comprising both wage employment and self-employment, is the largest source of employment. As we mentioned before, this segment of the labour force is not necessarily inferior to the formal sector, given the significant amount of worker transitions from formal to informal employment.

The multinomial logit analysis of movements between labour sectors allows us to determine, in statistical terms, the likelihood of workers to move from the initial sector to another sector, on the basis of their specific characteristics (see tables 2 and 3).

Table 2

Ecuador: multinomial logit analysis of transitions out of the formal sector, 2011-2012 (Estimated coefficients)

\begin{tabular}{|c|c|c|c|c|}
\hline \multirow[b]{2}{*}{ Variables } & \multicolumn{4}{|c|}{ From the formal sector to } \\
\hline & Informal waged & Informal self-employed & Unemployed & Out of the labour force \\
\hline \multirow{2}{*}{ Constant } & 1.391 & -2.305 & -3.387 & -1.548 \\
\hline & $(3.15)^{\star \star \star}$ & $(5.07)^{\star \star \star}$ & $(2.90)^{\star \star \star \star}$ & $(2.48)^{* *}$ \\
\hline \multirow{2}{*}{ Age } & -0.022 & 0.026 & -0.018 & 0.006 \\
\hline & $(2.56)^{\star \star}$ & $(3.52)^{\star \star \star}$ & $(0.90)$ & $(0.52)$ \\
\hline \multirow{2}{*}{ Male $^{\mathrm{a}}$} & -0.144 & 0.026 & -0.014 & 0.811 \\
\hline & $(0.78)$ & $(0.15)$ & $(0.04)$ & $(3.42)^{\star \star \star}$ \\
\hline \multirow{2}{*}{ Married $^{a}$} & -0.365 & 0.206 & -1.003 & -0.469 \\
\hline & $(1.93)^{\star}$ & $(1.20)$ & $(1.89)^{\star \star}$ & $(1.72)^{\star}$ \\
\hline \multirow{2}{*}{ Schooling } & -0.397 & -0.153 & -0.277 & -0.441 \\
\hline & $(8.93)^{\star \star \star}$ & $(3.69)^{\star \star \star}$ & $(2.66)^{\star \star \star}$ & $(7.02)^{\star \star \star}$ \\
\hline \multirow{2}{*}{ Experience } & -0.005 & -0.042 & -0.077 & -0.008 \\
\hline & $(0.40)$ & $(4.11)^{\star \star \star}$ & $(1.93)^{\star \star}$ & $(0.56)$ \\
\hline \multirow{2}{*}{ Coast } & -0.050 & 0.204 & 1.522 & -0.436 \\
\hline & $(0.23)$ & $(0.86)$ & $(1.97)^{\star \star \star}$ & $(1.42)$ \\
\hline \multirow{2}{*}{ Centre } & -0.069 & 0.388 & 1.503 & -0.618 \\
\hline & $(0.22)$ & $(1.34)$ & $(1.68)^{\star \star}$ & $(1.51)$ \\
\hline \multirow{2}{*}{ South } & -0.257 & 0.318 & 1.221 & 0.227 \\
\hline & $(0.87)$ & $(1.13)$ & $(1.33)$ & $(0.59)$ \\
\hline \multirow{2}{*}{ Log. Diff. earnings } & -0.017 & -0.176 & -0.778 & -0.887 \\
\hline & $(0.30)$ & $(4.13)^{\star \star \star}$ & $(10.17)^{\star \star \star}$ & $(17.91)^{\star \star \star}$ \\
\hline
\end{tabular}

Source: Author's calculations, on the basis of the Ecuadorian Survey of Urban Employment, Unemployment and Underemployment, 2011-2012.

Note: The coefficients reflect how the different worker characteristics and the percentage change in real wage affect the probability of moving from the initial sector to the final sector relative to the probability of staying in the initial sector. The informal sector is made up of wage workers employed in small, unregistered establishments with less than 10 employees, plus all independent and self-employed workers. Z-statistics are in parentheses; ${ }^{\star} p<0.1,{ }^{\star \star} p<0.05,{ }^{\star \star \star} p<0.01$.

a These are dummy variables; default categories are: male, marital status excluding married, and north region. 
Table 3

Ecuador: multinomial logit analysis of transitions out of the informal sector, 2011-2012 (Estimated coefficients)

\begin{tabular}{|c|c|c|c|c|c|c|c|c|}
\hline \multirow{2}{*}{ Variables Transitions } & \multicolumn{4}{|c|}{ From informal waged to } & \multicolumn{4}{|c|}{ From informal self-employed to } \\
\hline & $\begin{array}{l}\text { Formal } \\
\text { waged }\end{array}$ & $\begin{array}{l}\text { Informal self } \\
\text {-employed }\end{array}$ & Unemployed & $\begin{array}{l}\text { Out of the } \\
\text { labour force }\end{array}$ & $\begin{array}{l}\text { Formal } \\
\text { waged }\end{array}$ & $\begin{array}{l}\text { Informal } \\
\text { waged }\end{array}$ & Unemployed & $\begin{array}{c}\text { Out of the } \\
\text { labour force }\end{array}$ \\
\hline \multirow{2}{*}{ Constant } & -1.774 & -3.022 & -5.078 & -5.392 & -3.084 & 0.404 & -3.691 & -2.908 \\
\hline & $(3.50)^{\star \star \star}$ & $(5.65)^{\star \star \star}$ & $(4.21)^{\star \star \star}$ & $(5.37)^{\star \star \star}$ & $(6.61)^{\star \star \star}$ & $(0.88)$ & $(3.17)^{\star \star \star}$ & $(6.04)^{\star \star \star}$ \\
\hline \multirow{2}{*}{ Age } & -0.004 & 0.034 & 0.004 & 0.024 & -0.016 & -0.027 & -0.061 & 0.004 \\
\hline & $(0.43)$ & $(4.13)^{\star \star \star}$ & $(0.23)$ & $(1.63)$ & $(2.15)^{\star *}$ & $(3.95)^{\star \star \star}$ & $(3.21)^{\star \star \star}$ & $(0.62)$ \\
\hline \multirow{2}{*}{ Male $^{\mathrm{a}}$} & -0.334 & -0.154 & -0.594 & 0.744 & -0.436 & -0.589 & -0.346 & 1.078 \\
\hline & $(1.68)^{\star \star}$ & $(0.77)$ & $(1.28)$ & $(2.07)^{\star \star}$ & $(2.67)^{\star \star \star}$ & $(3.52)^{\star \star \star}$ & $(0.87)$ & $(6.44)^{\star \star \star}$ \\
\hline \multirow{2}{*}{ Married ${ }^{a}$} & 0.063 & 0.022 & -0.848 & -0.932 & 0.464 & -0.411 & -0.984 & -0.391 \\
\hline & $(0.29)$ & $(0.11)$ & $(1.58)$ & $(2.30)^{\star \star}$ & $(2.70)^{\star \star \star}$ & $(2.40)^{\star *}$ & $(1.95)^{\star *}$ & $(2.45)^{\star \star}$ \\
\hline \multirow{2}{*}{ Schooling } & 0.295 & 0.157 & 0.246 & 0.168 & 0.303 & -0.150 & 0.319 & -0.064 \\
\hline & $(5.21)^{\star \star \star}$ & $(2.73)^{\star \star \star}$ & $(1.91)^{\star \star}$ & $(1.63)$ & $(7.35)^{\star \star \star}$ & $(3.23)^{\star \star \star}$ & $(2.92)^{\star \star \star}$ & $(1.49)$ \\
\hline \multirow{2}{*}{ Experience } & -0.018 & -0.005 & 0.004 & -0.011 & -0.005 & -0.001 & -0.104 & -0.017 \\
\hline & $(1.47)$ & $(0.48)$ & $(0.19)$ & $(0.59)$ & $(0.53)$ & $(0.15)$ & $(02.48)^{\star \star}$ & $(2.41)^{\star \star}$ \\
\hline \multirow{2}{*}{ Coast } & -0.565 & 0.187 & 0.135 & -0.037 & -0.332 & -0.165 & 0.577 & 0.430 \\
\hline & $(2.39)^{\star *}$ & $(0.75)$ & $(0.24)$ & $(0.08)$ & $(1.52)^{\star \star}$ & $(0.75)$ & $(0.87)$ & $(1.93)^{\star \star}$ \\
\hline \multirow{2}{*}{ Centre } & 0.095 & -0.086 & 0.334 & -0.270 & -0.040 & -0.168 & 0.325 & -0.164 \\
\hline & $(0.32)$ & $(0.26)$ & $(0.47)$ & $(0.47)$ & $(0.15)$ & $(0.59)$ & $(0.37)$ & $(0.56)$ \\
\hline \multirow{2}{*}{ South } & -0.499 & -0.466 & 0.167 & 0.099 & -0.132 & -0.110 & 1.318 & 0.406 \\
\hline & $(1.64)$ & $(1.33)$ & $(0.22)$ & $(0.16)$ & $(0.50)$ & $(0.39)$ & $(1.74)^{\star \star}$ & $(1.45)$ \\
\hline \multirow{2}{*}{ Log. Diff. earnings } & 0.034 & -0.283 & -0.942 & -1.146 & 0.126 & 0.174 & -0.636 & -0.661 \\
\hline & $(0.44)$ & $(4.28)^{\star \star \star}$ & $(9.89)^{\star \star \star}$ & $(13.22)^{\star \star \star}$ & $(3.42)^{\star \star \star}$ & $(4.38)^{\star \star \star}$ & $(7.69)^{\star \star \star}$ & $(19.63)^{\star \star \star}$ \\
\hline
\end{tabular}

Source: Author's calculations on the basis of the Ecuadorian Survey of Urban Employment, Unemployment and Underemployment, 2011-2012.

Note: The coefficients reflect how the different worker characteristics and the percentage change in real wage affect the probability of moving from the initial sector to the final sector relative to the probability of staying in the initial sector. The informal sector is made up of wage workers employed in small, unregistered establishments with less than 10 employees, plus all independent and self-employed workers. Z-statistics are in parentheses; ${ }^{*} p<0.1,{ }^{* *} p<0.05,{ }^{* * *} p<0.01$.

a Dummy variables; default categories are: male, marital status excluding married, and north region.

The results obtained show that workers become less likely to move from formal status to informal status as their level of education increases. On average, workers who transitioned to informal wage employment and self-employment had completed six and seven years of studies, respectively.

With regard to experience, the probability of moving into the informal sector, specifically to selfemployment, decreases as the worker's experience increases. It is worth noting that the mean years of experience for individuals who started their own business is 8, which represents a considerable number of years of training. Aroca and Maloney (1998) found that the informal self-employed sector is a desirable destination for workers, but it requires an accumulation of financial and human capital. Thus, the mean years of experience suggests that workers first accumulate savings and knowledge, which can then be used to start a business. The characteristics of each sector of the labour market and the specificities of a job determine the differences in wages between sectors. Tansel and Oznur (2012) examine whether informal workers are paid less than similar workers in the formal sector. The authors found that unobserved fixed effects combined with observable worker characteristics explained the pay differentials between formal and informal employment. 
Thus, unobserved characteristics such as personal production capacity, character traits and management quality could affect workers' productivity and, therefore, the wage differential. As expected, the logit results show that the probability of moving from formal employment to self-employment decreases as the percentage difference, in real wages, between the initial sector and final sector rises. The sample mean difference in real earnings showed that the individuals who moved in this direction earned less. Thus, if this difference increases, workers would be less likely to move into the informal sector.

Similarly, we follow the transitions between formal employment and the two statuses in which there is no participation in the labour market: unemployed and out of the labour force. In both cases, the probability of these transitions decreases as the level of education increases. It is also important to note that the probability of workers moving from the formal sector to unemployment decreases as the years of experience increase.

Moving to the second multinomial logit analysis, an interesting pattern arises in the flows from informal wage employment to the formal sector. If we consider that the number of workers with higher levels of education raises the mean years of schooling in the formal sector, annex table A1.3 shows that the mean years of schooling of individuals who remained as informal wage workers is 5 , while that of individuals who moved to the formal status is 6 . The results suggest that individuals with higher levels of schooling are more likely to enter formal sector employment. This correlation may imply that workers start out in the informal sector - seeing it as an employment option while they continue their education - and after raising their level of instruction and skills, they seek better labour conditions in the formal sector.

The findings also show that education has a positive effect on the transitions from informal wage employment to self-employment, in other words, movements within the informal sector. However, the percentage difference of the real wage between the initial and final sector has a negative impact on this flow.

The third section of annex table A1.3 presents the transitions from self-employment to the other labour sectors. The probability of moving from self-employment to the formal sector is associated with two variables: education and the percentage difference in real wages. Regarding the first, individuals with higher levels of education tend to move to better jobs in the formal sector. The mean differences in the real wage of the workers who moved to the formal sector is positive and significant, thus if this difference increases, so will the probability of moving to the formal sector.

The results suggest that individuals with higher levels of education are less likely to move from self-employment to informal wage employment; indicating that workers prefer the autonomy that the latter probably would not offer. The difference in real wage in this instance is positive.

Lastly, with regard to the transition from the informal sector (both waged and self-employed) to unemployed and out of the labour force, the main finding is that the percentage real-wage differential negatively influences these two flows.

In order to have a better idea of the economic significance of the effect of observable worker characteristics on the different transitions across the labour sectors, we use the two multinomial logit models to run simulations, assigning specific worker characteristics. ${ }^{5}$ We first analyse the effect of years of experience on the probability of moving from the formal sector to other sectors and the probability of remaining in the same sector. For this estimation, we set the age at 38 years and education level at secondary school and we then compared the probabilities of transition or continuance for both men and women (annex figures A1.1A-A1.1E). For both sexes, more years of experience led to a significant increase in the probability of continuance in formal wage employment. The transition probabilities show that exit rates to the informal and unemployed sectors decline with years of experience.

5 Simulation results for other characteristics are omitted to save space, but are available from the author on request. 
We also analysed the effect of different levels of education for the second and third logit models. Here, we again set the age at 38 years and assigned 10 years of experience (see annex figures A1.2A to A1.21). Interestingly, as the level of education increases, so does the probability of moving from the informal sector (both wage employment and self-employment) to the formal sector. Analysis of the probability of continuance as an informal wage worker shows that this decreases as the level of education rises. Using the same worker characteristics, the probability of transition from wage employment to selfemployment, unemployment and out of the labour force increases as the level of education increases. Given the above-mentioned worker characteristics, the pattern in the probability of continuance in self-employment is interesting: this probability increases as workers attain secondary education then declines thereafter. Lastly, the probability of transition from self-employment to wage employment or out of the labour force decreases as the level of education increases.

\section{Concluding remarks}

Informality is a widespread phenomenon which involves a significant share of the labour force in many developing and transition economies. The study provides an overview of the dynamics of the formal and informal sectors and some specific transition patterns within the labour sectors. We specify a transition matrix and a multinomial logit model to identify the movements across the sectors and the effect of each worker characteristic on the probability of transition to or from a sector.

The results observed in the transition matrix suggest dynamic flows not only in and out of the labour market, but also across the sectors. Nonetheless, these results can be considered to be within the normal percentage range of movements found in similar analyses of labour mobility in Latin America. The sectoral flows involving employed individuals suggest that job opportunities are sought in both the formal and informal sectors, as illustrated by flows in the transition matrix towards the formal sector, informal wage employment and self-employment.

The multinomial logit analysis was applied in view of the fact that transition matrices do not consider observable characteristics that can affect workers' choice of sector. This approach indicated that education, years of experience, and other characteristics influence the type of employment selected and, consequently, the transitions to or continuance in the various sectors.

The findings presented in the study point to significant interaction between the formal and informal sectors. The patterns of mobility imply that informal employment should be viewed as a desirable destination, as is the formal sector. The three employment statuses present various advantages and disadvantages, depending on the individual's preferences and abilities.

Lastly, the possible labour market flows from formal employment to informal wage and selfemployment have important policy implications: policies should vary depending on whether individuals are in formal or informal employment. Consequently, it may be worthwhile to question the importance and effectiveness of existing labour market, productivity and social protection policies. If informal workers enter this sector involuntarily, policymakers must focus on aspects such as wage rigidities and be observant of companies' social protection obligations. Another important issue is the impact of informal employment on the economy: while informality is favourable from an individual standpoint, a certain formalization of the economy is necessary from a societal perspective. In most cases, entry into the informal sector is the optimal decision taken by workers based on their preferences, level of education and the restrictions or limitations of the formal sector. However, a large informal workforce is not necessarily the best option for the society as a whole, since formalization is the easiest way to organize the labour force and the associated legal framework. 
In the case of voluntary entry into the informal sector, policymakers must be aware of the heterogeneity and complexities of jobs and working conditions within the informal sector and take into account the inefficiencies in labour legislation and low levels of formal sector productivity. ${ }^{6}$ By this reckoning, workers who are in the informal sector voluntarily should find ways to substitute the protection offered by formal institutions; this would call for an in-depth assessment of the quality of various jobs rather than legal protections. It is often thought self-evident that, given the low levels of human capital in the informal sector, improving the accessibility and quality of education will increase worker productivity and pay in the formal sector. However, when choosing the sector in which they prefer to work, individuals take not only their potential earnings into account, but also all other elements and advantages associated with each job or sector.

\section{Bibliography}

Aroca, P. and W. Maloney (1998), "Logit analysis in a rotating panel context and an application to self-employment decisions", Policy Research Working Paper, No. 2069, Washington, D.C., World Bank.

Bacheta, M., E. Ernst and J. Bustamante (2009), "Globalization and informality in time of crisis", Globalization and Informal Jobs in Developing Countries, Geneva, International Labour Organization (ILO)/World Trade Organization (WTO).

Bosch, M. and W. Maloney (2005), "Labor market dynamics in developing countries. Comparative analysis using continuous time Markov processes", Policy Research Working Paper, No. 3583, Washington, D.C.

Canelas, C. (2014), "Minimum wage and informality in Ecuador", Wider Working Paper, No. 2014/006, Helsinki, World Institute for Development Economics Research (UNU-WIDER).

Cea, S. and M. I. Contreras (2008), "Transiciones laborales: evidencia para datos de panel", thesis, Santiago, University of Chile.

Charmes, J. (2009), "Concepts, measurement and trends", Is Informal Normal? Towards More and Better Jobs in Developing Countries, J. Jütting and J. Laiglesia (eds.), Paris, Organization for Economic Cooperation and Development (OECD).

Duryea, S. and othes (2006), "For better or for worse? Job and earnings mobility in nine middle- and low-income countries", Brookings Trade Forum. Global Labor Markets?, Washington, D.C., Brookings Institution Press.

Fields, G. (2009), "Segmented labor market models in developing countries", The Oxford Handbook of Philosophy of Economics, D. Ross and H. Kincaid (eds.), Oxford University Press.

(1972), "Rural-urban migration, urban unemployment and underemployment, and job-search activity in LDC's", Journal of Development Economics, vol. 2, No. 2, Amsterdam, Elsevier.

Günther, I. and A. Launov (2006), "Competitive and segmented informal labor markets", IZA Discussion Papers, No. 2349, Bonn, Institute for the Study of Labor (IZA).

Harris, J. and M. Todaro (1970), "Migration, unemployment and development: a two-sector analysis", American Economic Review, vol. 60, No. 1, Nashville, Tennessee, American Economic Association.

ILO (International Labour Organization) (2013), Measuring Informality: A Statistical Manual on the Informal Sector and Informal Employment, Geneva.

Jiménez, M. (2011), "La economía informal y el mercado laboral en la Argentina: un análisis desde la perspectiva del trabajo decente", Working Paper, No. 116, La Plata, Center for Distributive, Labor and Social Studies (CEDLAS).

Jütting, J., J. Parlevliet and T. Xenogiani (2008), "Informal employment re-loaded", IDS Bulletin, vol. 39, No. 2, Institute of Development Studies.

Lehmann, H. and N. Pignatti (2008), "Informal employment relationships and labor market segmentation in transition economies: evidence from Ukraine", IZA Discussion Paper, No. 3269, Bonn, Institute for the Study of Labor (IZA).

Maloney, W. (2004), "Informality revisited", World Development, vol. 32, No. 7, Amsterdam, Elsevier.

\footnotetext{
6 See Maloney (2004).
} 
(1999), "Does informality imply segmentation in urban labor markets? Evidence from sectorial transitions in Mexico", The World Bank Economic Review, vol. 13, No. 2, Oxford University Press.

Mandelman, F. and G. Montes-Rojas (2009), "Is self-employment and micro-entrepreneurship a desired outcome?", World Development, vol. 37, No. 12, Amsterdam, Elsevier.

Perry, G. and others (2007), "The razón de ser of the informal sector", Informality: Exit and Exclusion, Washington, D.C., World Bank.

Slonimczyk, F. and V. Gimpelson (2013), "Informality and mobility: evidence from Russian panel data", IZA Discussion Paper, No. 7703, Bonn, Institute for the Study of Labor (IZA).

Soto, H. de (2000), The Mystery of Capital: Why Capitalism Triumphs in the West and Fails Everywhere Else, New York, Basic Books.

Tansel, A. and E. Oznur (2012), "The formal/informal employment earnings gap: evidence from Turkey", IZA Discussion Paper, No. 6556, Bonn, Institute for the Study of Labor (IZA).

World Bank (2012), Ecuador: the Faces of Informality, Report No. 67808-EC, Washington, D.C. 


\section{Annex A1}

Table A1.1

Ecuador: worker mobility across sectors of the labour market, 2007-2008

(Percentages)

\begin{tabular}{lccccccc}
\hline \multirow{2}{*}{ Initial sector } & \multicolumn{7}{c}{ Final status } \\
\cline { 2 - 7 } & $\begin{array}{c}\text { Formal } \\
\text { waged }\end{array}$ & $\begin{array}{c}\text { Informal } \\
\text { waged }\end{array}$ & $\begin{array}{c}\text { Informal self- } \\
\text { employed }\end{array}$ & Unemployed & $\begin{array}{c}\text { Outside the } \\
\text { labour force }\end{array}$ & Total & $P_{i}$ \\
\hline Formal waged & 79 & 6 & 6 & 2 & 6 & 100 & 27 \\
\hline Informal waged & 21 & 46 & 18 & 4 & 12 & 100 & 13 \\
\hline Informal self-employed & 8 & 7 & 67 & 1 & 16 & 100 & 22 \\
\hline Unemployed & 23 & 11 & 25 & 19 & 22 & 100 & 4 \\
\hline Outside the labour force & 4 & 4 & 8 & 3 & 81 & 100 & 34 \\
\hline$P_{j}$ & 26 & 10 & 24 & 3 & 37 & 500 &
\end{tabular}

Source: Author's calculations on the basis of the Ecuadorian Survey of Urban Employment, Unemployment and Underemployment, 2011-2012.

Note: $\quad P_{i}$ is the relative size of a sector in the initial period; $P_{j}$ is the relative size of a sector in the final period.

Table A1.2

Ecuador: worker mobility across sectors of the labour market, 2009-2010

(Percentages)

\begin{tabular}{|c|c|c|c|c|c|c|c|}
\hline \multirow{2}{*}{ Initial sector } & \multicolumn{6}{|c|}{ Final status } & \multirow[b]{2}{*}{$P_{i}$} \\
\hline & $\begin{array}{l}\text { Formal } \\
\text { waged }\end{array}$ & $\begin{array}{l}\text { Informal } \\
\text { waged }\end{array}$ & $\begin{array}{l}\text { Informal self- } \\
\text { employed }\end{array}$ & Unemployed & $\begin{array}{l}\text { Outside the } \\
\text { labour force }\end{array}$ & Total & \\
\hline Formal waged & 75 & 8 & 8 & 2 & 6 & 100 & 25 \\
\hline Informal waged & 19 & 47 & 17 & 4 & 13 & 100 & 12 \\
\hline Informal self-employed & 10 & 9 & 61 & 3 & 18 & 100 & 23 \\
\hline Unemployed & 24 & 14 & 16 & 16 & 30 & 100 & 5 \\
\hline Outside the labour force & 5 & 4 & 7 & 3 & 81 & 100 & 35 \\
\hline$P_{j}$ & 27 & 12 & 21 & 4 & 37 & & \\
\hline
\end{tabular}

Source: Author's calculations on the basis of the Ecuadorian Survey of Urban Employment, Unemployment and Underemployment, 2011-2012.

Note: $\quad P_{i}$ is the relative size of a sector in the initial period; $P_{j}$ is the relative size of a sector in the final period. 
Table A1.3

Ecuador: summary statistics using the first definition of the informal sector, 2011-2012a

\begin{tabular}{|c|c|c|c|c|c|}
\hline \multirow[b]{2}{*}{ Worker transitions between sectors } & \multicolumn{5}{|c|}{ Mean } \\
\hline & $\begin{array}{c}\text { Number of } \\
\text { observations }\end{array}$ & $\begin{array}{c}\text { Age } \\
\text { (years) }\end{array}$ & $\begin{array}{c}\text { Schooling } \\
\text { (years) }\end{array}$ & $\begin{array}{l}\text { Experience } \\
\text { (years) }\end{array}$ & $\begin{array}{c}\text { Initial real } \\
\text { wage (USD) }\end{array}$ \\
\hline \multicolumn{6}{|l|}{ From the formal sector to } \\
\hline \multirow[t]{2}{*}{ Formal sector } & 1841 & 39.2 & 7.4 & 9.8 & 466.2 \\
\hline & & (12.91) & (1.93) & (10.38) & $(505.70)$ \\
\hline \multirow[t]{2}{*}{ Informal sector (wage employment) } & 171 & 35.6 & 5.9 & 7.3 & 257.4 \\
\hline & & (12.95) & $(1.73)$ & $(9.02)$ & (221.01) \\
\hline \multirow[t]{2}{*}{ Informal sector (self-employment) } & 178 & 41.6 & 6.8 & 8.1 & 366.9 \\
\hline & & (12.55) & (1.99) & $(8.97)$ & (392.70) \\
\hline \multirow[t]{2}{*}{ Unemployed } & 38 & 29.7 & 7.1 & 3.3 & 338.3 \\
\hline & & $(9.67)$ & (1.91) & (5.03) & $(296.44)$ \\
\hline \multirow[t]{2}{*}{ Outside the labour force } & 156 & 40.9 & 6.7 & 10.7 & 375.1 \\
\hline & & (20.14) & $(2.02)$ & $(13.65)$ & (466.04) \\
\hline \multicolumn{6}{|c|}{ From the informal sector (wage employment) to } \\
\hline \multirow[t]{2}{*}{ Formal sector } & 196 & 34.0 & 6.1 & 6.2 & 209.5 \\
\hline & & (12.69) & (1.73) & (8.19) & $(114.56)$ \\
\hline \multirow[t]{2}{*}{ Informal sector (wage employment) } & 438 & 37.3 & 5.2 & 8.66 & 192.6 \\
\hline & & $(14.30)$ & $(1.61)$ & $(10.34)$ & $(81.24)$ \\
\hline \multirow[t]{2}{*}{ Informal sector (self-employment) } & 190 & 42.4 & 5.3 & 10.5 & 180.1 \\
\hline & & (12.50) & $(1.76)$ & $(12.31)$ & $(98.84)$ \\
\hline \multirow[t]{2}{*}{ Unemployed } & 38 & 32.2 & 5.9 & 7.6 & 178.2 \\
\hline & & (12.69) & $(1.66)$ & (12.22) & $(96.84)$ \\
\hline \multirow[t]{2}{*}{ Outside the labour force } & 106 & 36.4 & 5.5 & 6.8 & 129.5 \\
\hline & & $(17.52)$ & (1.93) & $(12.10)$ & (78.03) \\
\hline \multicolumn{6}{|c|}{ From the informal sector (self-employment) to } \\
\hline \multirow[t]{2}{*}{ Formal sector } & 200 & 42.6 & 6.8 & 11.3 & 290.8 \\
\hline & & $(14.06)$ & $(1.97)$ & (11.08) & (394.28) \\
\hline \multirow[t]{2}{*}{ Informal sector (wage employment) } & 191 & 42.1 & 5.32 & 11.4 & 180.7 \\
\hline & & (14.94) & $(1.86)$ & $(12.91)$ & $(324.39)$ \\
\hline \multirow[t]{2}{*}{ Informal sector (self-employment) } & 1591 & 48.0 & 5.5 & 13.6 & 215.0 \\
\hline & & (13.53) & $(1.90)$ & $(12.03)$ & (302.08) \\
\hline \multirow[t]{2}{*}{ Unemployed } & 34 & 30.4 & 7.2 & 4.0 & 107.9 \\
\hline & & (10.62) & (1.65) & $(4.12)$ & $(164.50)$ \\
\hline \multirow[t]{2}{*}{ Outside the labour force } & 350 & 48.0 & 5.4 & 10.7 & 90.7 \\
\hline & & (19.53) & $(1.90)$ & $(13.73)$ & $(137.73)$ \\
\hline
\end{tabular}

Source: Author's calculations on the basis of the Ecuadorian Survey of Urban Employment, Unemployment and Underemployment, 2011-2012.

a This definition of the informal sector refers to wage workers employed by small establishments with less than 10 employees and are not registered, plus all independent and self-employed workers. Standard errors are in parentheses. 
Figure A1.1

Effect of years of experience on various labour market transitions, by gendera

(Probabilities)
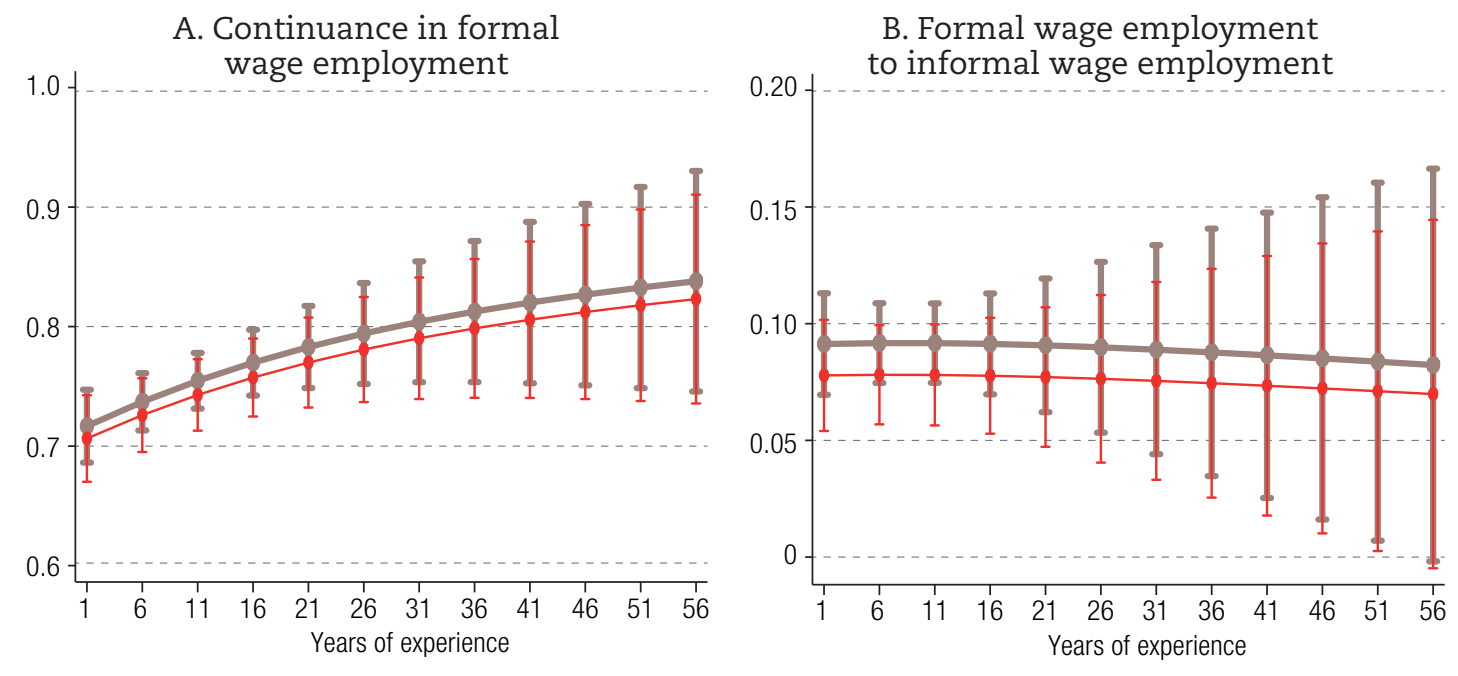

C. Formal wage employment

to self-employment
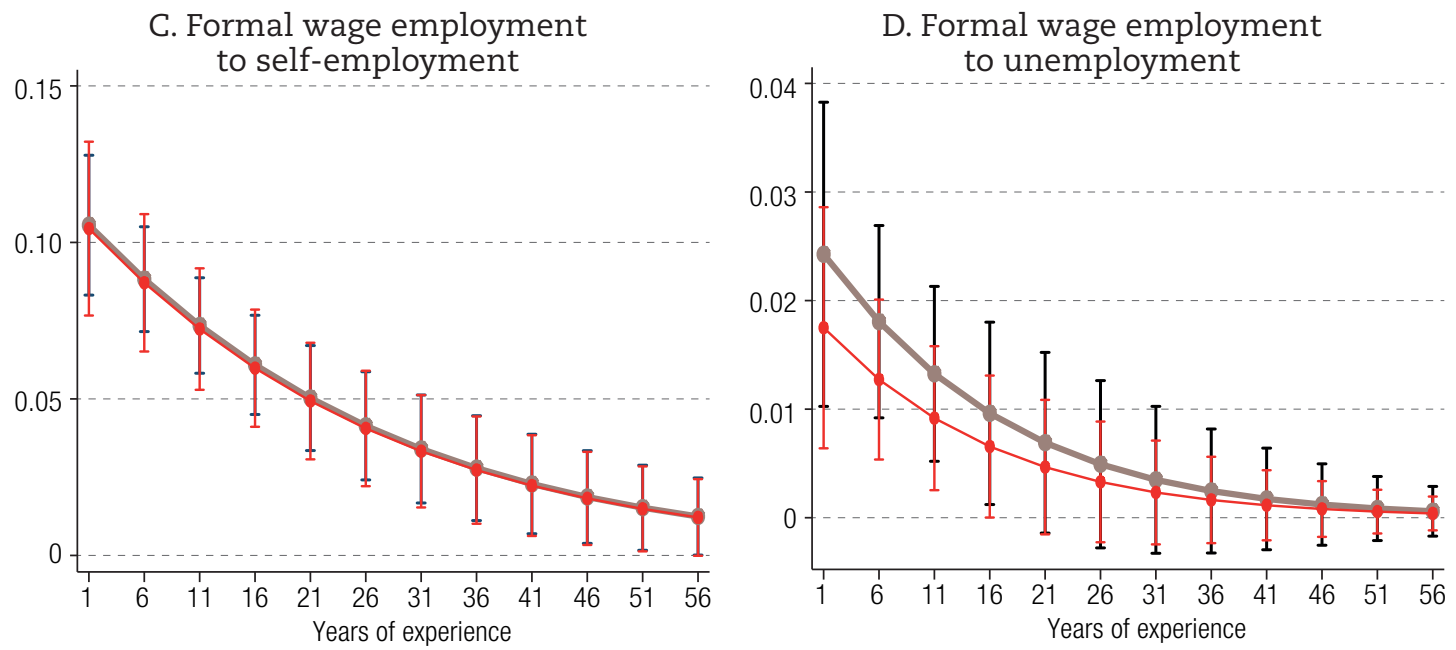

E. Formal wage employment to outside the labour force

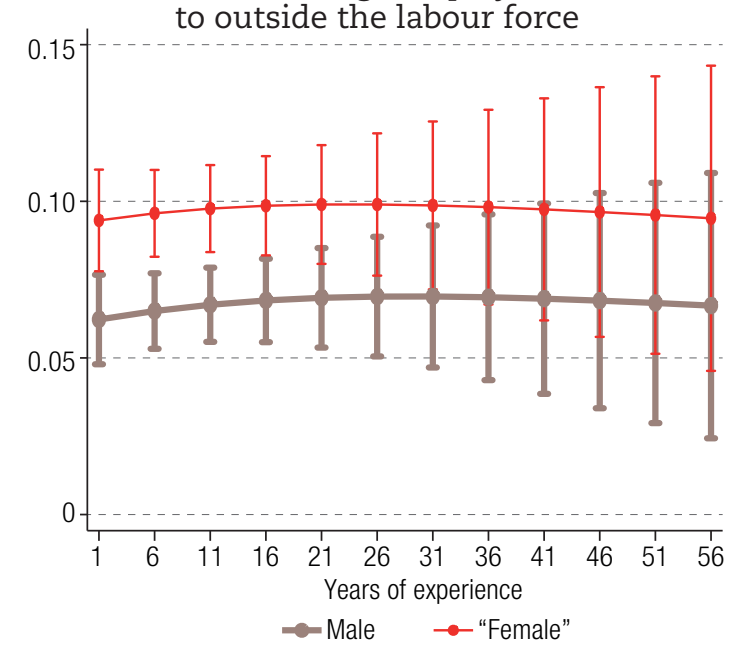

Source: Author's calculations on the basis of estimation results.

a Predictive margins with 95\% confidence intervals. 
Figure A1.2

Effect of level of education on various labour market transitions, by gendera

(Probabilities)
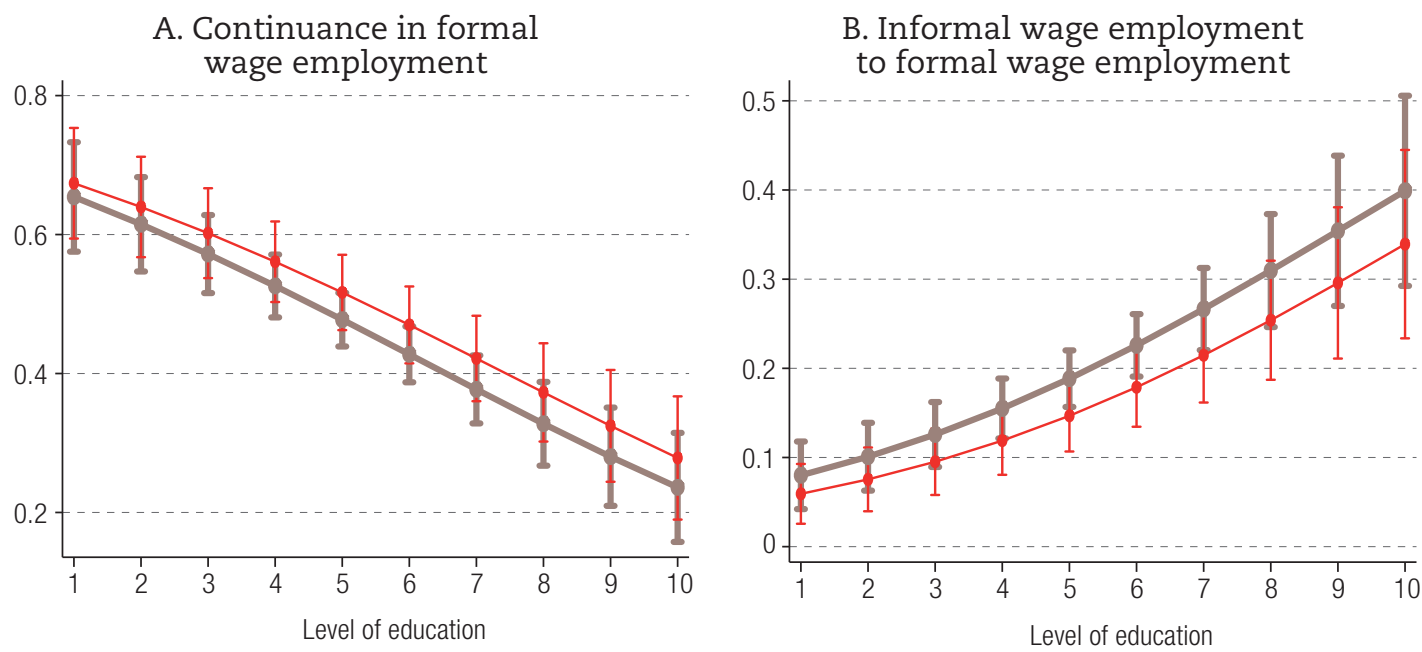

C. Informal wage employment to self-employment

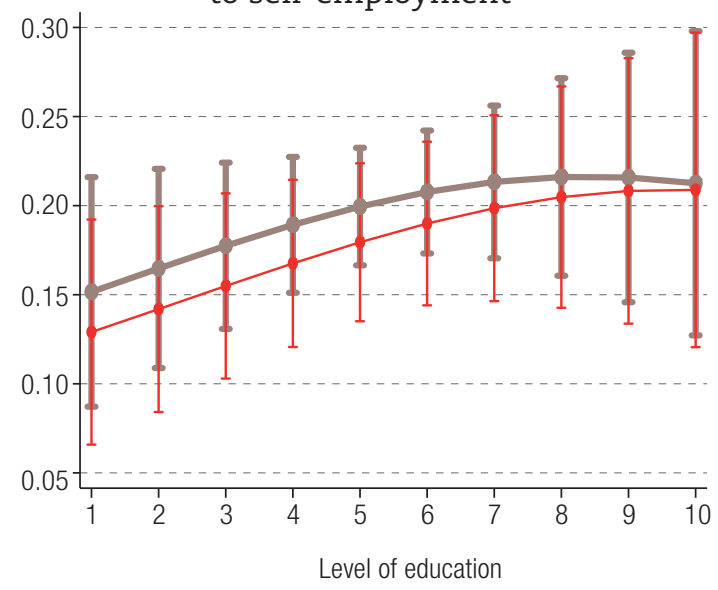

D. Informal wage employment to unemployment

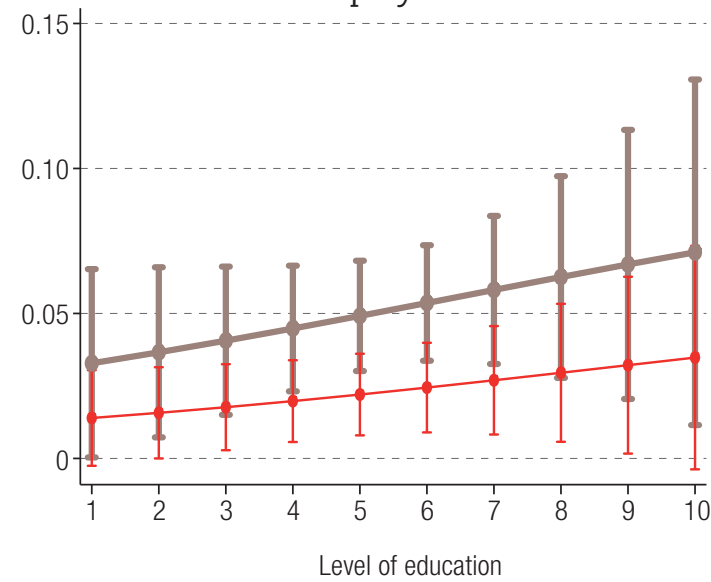

E. Informal wage employment to outside the labour force

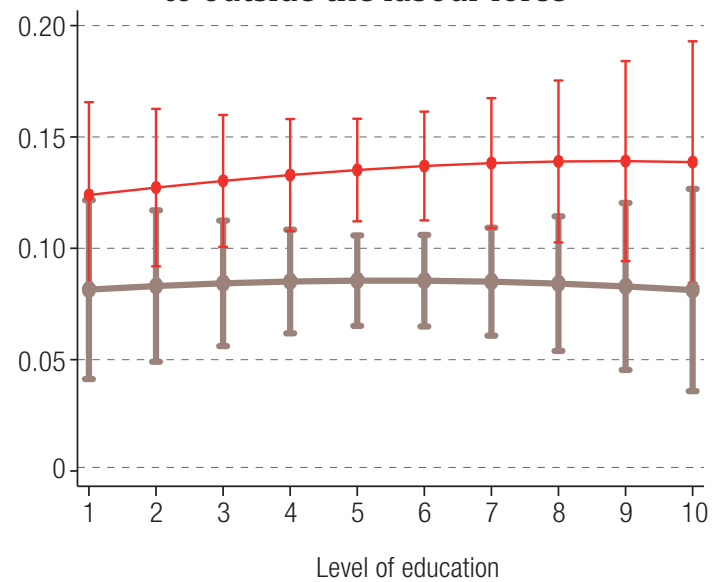

F. Self-employment to formal wage employment

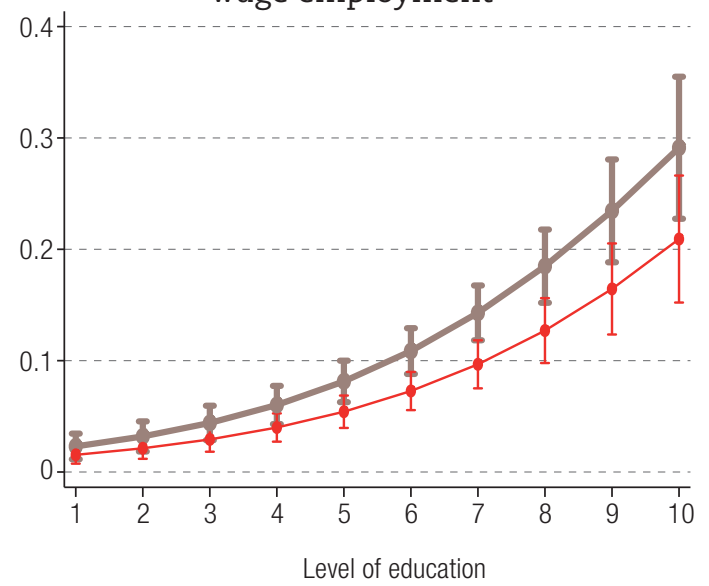


Figure A1.2 (concluded)

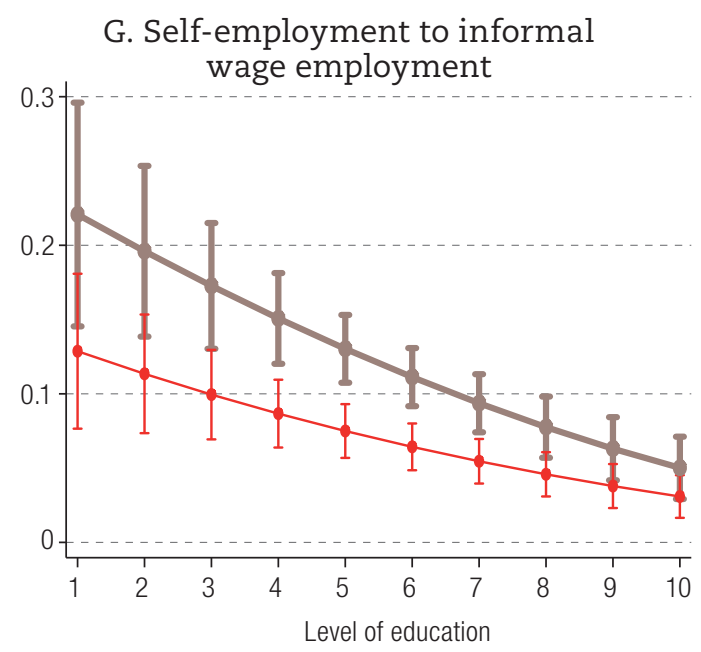

H. Continuance in self-employment

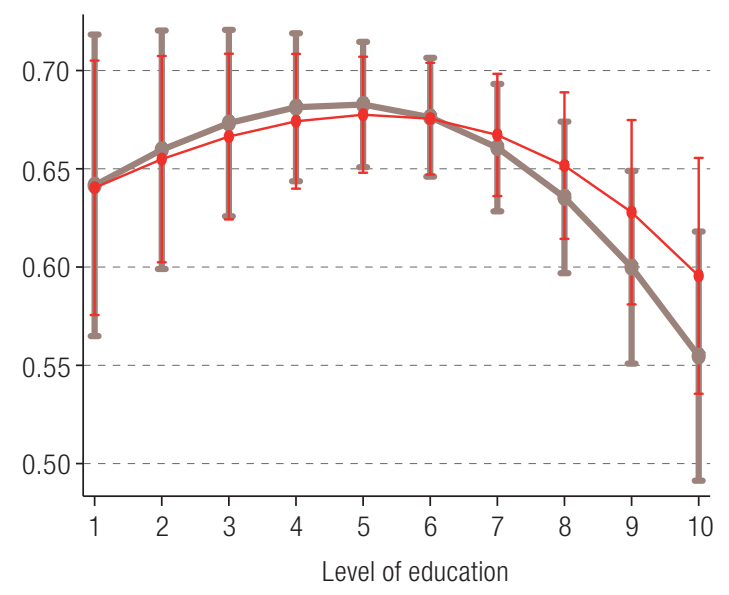

I. Self-employment to unemployment
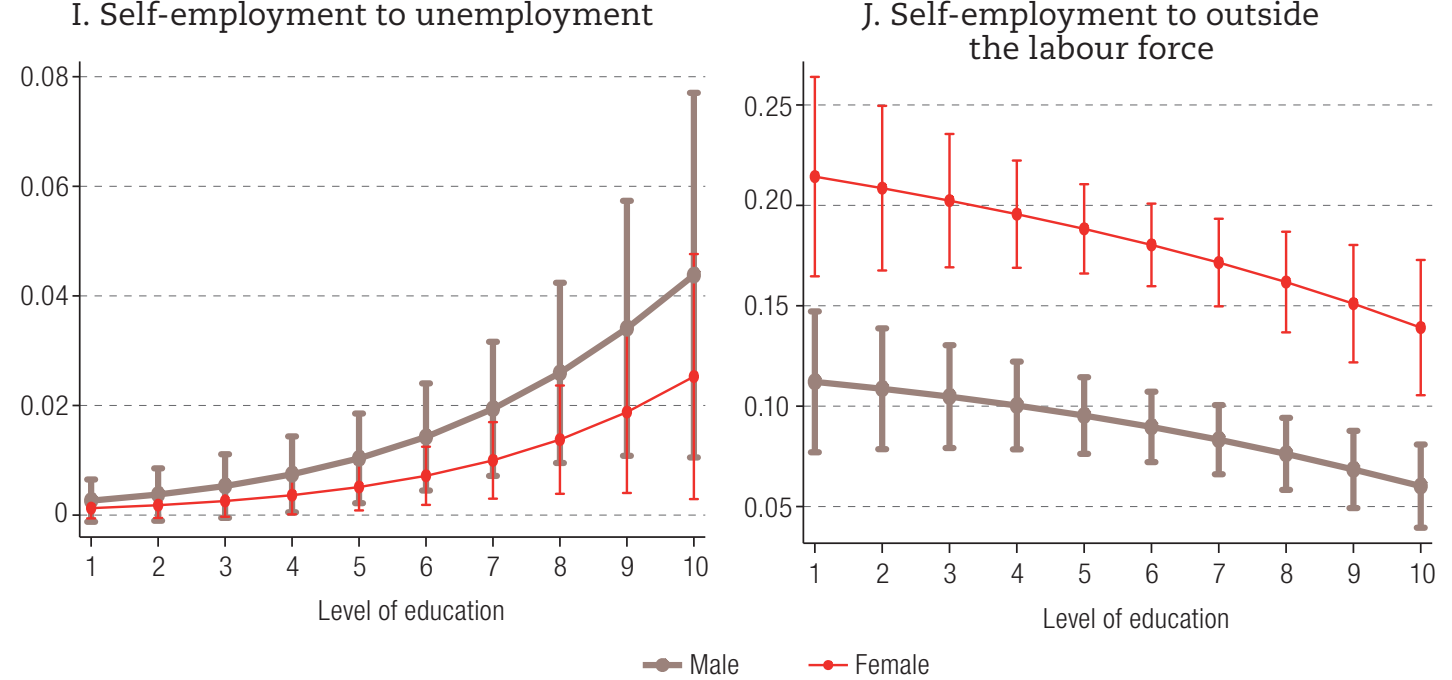

Source: Author's calculations on the basis of estimation results.

a Predictive margins with 95\% confidence intervals. 